\title{
Akumulasi Biomasa Fitoplankton yang Diukur sebagai Klorofil-a di Perairan Teluk Doreri, Provinsi Papua Barat
}

\author{
Alianto $^{*}$, Yorry Kambanussy1, Luky Sembel ${ }^{2}$, dan Baigo Hamuna ${ }^{3}$ \\ 'Program Studi Manajemen Sumberdaya Perairan, Universitas Papua \\ 2Program Studi llmu Kelautan, Universitas Papua \\ Jl Gunung Salju, Amban, Manokwari, Papua Barat, 98314 Indonesia \\ 3Program Studi llmu Kelautan, Universitas Cenderawasih \\ Jl. Camp Wolker Waena, Jayapura, Papua 99351 Indonesia \\ Email: a.alianto@unipa.ac.id
}

\begin{abstract}
The Accumulation of Phytoplankton Biomass Measured as Chlorophyll-a in Doreri Bay, West Papua
\end{abstract}

The accumulation of phytoplankton biomass measured as chlorophyll-a is highly dependent on the availability of ammonia and silicate in the waters. This study aims to determine the status based on chlorophyll-a concentration and its relationship with ammonia and silicate in the waters of Doreri Bay, Manokwari Regency, West Papua Province. It was conducted at 3 stations located in coastal waters and the inside of the bay and 7 stations located outside the Doreri Bay. Seawater sampling was taken three times at an interval of one in every month in a row at 10 research stations. Seawater sampling for chlorophyll-a measurements was carried out at 10 research stations. Seawater sampling for measurement of ammonia and silicate was carried out at 4 stations located outside the bay. Measurement of chlorophyll-a concentration, ammonia, and silicate used Lorenzen method, the Phenate method, and the Molybdosilicate method, respectively. The results show that chlorophyll-a concentration from stations 1-10 ranged from 0.23 to $3.77 \mu \mathrm{g} / \mathrm{L}$ with an average of $0.82 \mu \mathrm{g} / \mathrm{L}$. Chlorophyll-a concentrations was high at stations 1, 5 and 6 in coastal waters and the inside of the bay with concentrations ranging from 0.46-3.77 $\mu \mathrm{g} / \mathrm{L}$ with an average of 2.11 $\mu \mathrm{g} / \mathrm{L}$. Chlorophyll-a concentration decreased at stations $2,3,4,7,8,9$ and 10 which are located outside the bay with concentrations ranging from 0.37 to $0.96 \mu \mathrm{g} / \mathrm{L}$ with an average of $0.66 \mu \mathrm{g} / \mathrm{L}$. Ammonia and silicate concentrations at stations $4,8,9$ and 10, respectively, ranging from 2.35-4.1 1 $\mu \mathrm{M}$ with an average of $2.64 \mu \mathrm{M}$ and 2.00-7.50 $\mu \mathrm{M}$ with an average of $3.91 \mu \mathrm{M}$. The results of analysis show that the relationships of chlorophyll-a concentration with ammonia and silicate showed positive and negative relationships, respectively.

Keywords: Phytoplankton biomass; chlorophyll-a; ammonia; silicate; Doreri Bay

\begin{abstract}
Abstrak
Akumulasi biomasa fitoplankton yang diukur sebagai klorofil-a sangat tergantung pada ketersediaan amonia dan silikat di perairan. Penelitian bertujuan untuk mengetahui status berdasarkan konsentrasi klorofil-a serta hubungannya dengan amonia dan silikat di perairan Teluk Doreri, Kabupaten Manokwari, Provinsi Papua Barat. Penelitian dilakukan pada 3 stasiun yang berada di perairan pantai dan bagian dalam teluk serta 7 stasiun yang berada di bagian luar Teluk Doreri. Pengambilan contoh air laut diambil sebanyak tiga kali dengan interval satu kali setiap bulan secara berturut-turut pada 10 stasiun penelitian. Pengambilan contoh air laut untuk pengukuran klorofil-a dilakukan pada 10 stasiun penelitian. Pengambilan contoh air laut untuk pengukuran amonia dan silikat dilakukan pada 4 stasiun yang berada di bagian luar teluk. Pengukuran konsentrasi klorofil-a menggunakan metode Lorenzen, amonia menggunakan metode Phenate, dan silikat menggunakan metode Molibdosilikat. Hasil pengukuran diperoleh konsentrasi klorofil-a dari stasiun 1-10 berkisar dari 0,23-3,77 $\mathrm{\mu g} / \mathrm{L}$ dengan rata-rata sebesar 0,82 $\mathrm{\mu g} / \mathrm{L}$. Konsentrasi klorofil-a tinggi pada stasiun 1, 5 dan 6 yang berada di perairan pantai dan bagian
\end{abstract}


dalam teluk dengan konsentrasi berkisar dari 0,46-3,77 $\mathrm{gg} / \mathrm{L}$ dengan rata-rata sebesar $2,11 \mu \mathrm{g} / \mathrm{L}$. Konsentrasi klorofil-a berkurang pada stasiun 2, 3, 4, 7, 8, 9 dan 10 yang berada di bagian luar teluk dengan konsentrasi berkisar dari 0,37-0,96 $\mu \mathrm{g} / \mathrm{L}$ dengan rata-rata sebesar 0,66 $\mu \mathrm{g} / \mathrm{L}$. Konsentrasi amonia dan silikat pada stasiun 4, 8, 9 dan 10 secara berturut-turut berkisar dari 2,35-4,11 $\mu \mathrm{M}$

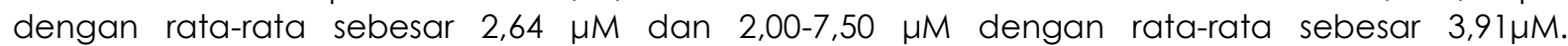
Berdasarkan analisis hubungan konsentrasi klorofil-a dengan amonia dan silikat secara berturutturut menunjukkan hubungan positif dan negatif.

Kata Kunci : Biomasa fitoplankton; klorofil-a; amonia; silikat; Teluk Doreri

\section{PENDAHULUAN}

Salah satu yang menjadi kendala dalam mengukur biomasa fitoplankton adalah karena ukurannya yang mikroskopis. Pendekatan yang sering digunakan untuk mengetahui biomasa fitoplankton adalah dengan mengukur konsentrasi klorofil-a (Hourany et al., 2017; Szymczak-Zylaa et al., $2011)$. Pendekatan ini digunakan karena lebih mewakili tiga kelompok ukuran fitoplankton dibandingkan dengan pendekatan lainnya seperti menghitung jumlahnya. Menghitung jumlah fitoplankton yang berukuran mikroskopis tersebut sangat sulit serta memerlukan teknologi dan keterampilan yang tinggi serta jangka waktu yang diperlukan relatif lama.

Selain itu, pendekatan tersebut di atas dilakukan karena klorofil-a dimiliki atau terdapat pada semua jenis fitoplankton (Rozema et al., 2017). Oleh karena itu keberadaan dan fluktuasi konsentrasi klorofila digunakan sebagai petunjuk kesuburan perairan (Prihatin et al., 2018). Selain itu bila konsentrasi klorofil-a tinggi sampai berada pada atau level tertentu sebagai petunjuk terjadinya blooming fitoplankton (Chakraborty \& Feudel, 2014). Fenomena blooming yang ditunjukkan akumulasi klorofila dengan konsentrasi tinggi umumnya terdapat di perairan pantai atau teluk yang dangkal (Rimet \& Bouchez, 2012).

Pada perairan pantai, konsentrasi klorofil-a berfluktuasi atau cenderung tinggi sebagai respon fitoplankton atas perubahan kondisi lingkungan perairan yang sangat tinggi (Szymczak-Zylaa et al., 2017). Fenomena ini di sebagian besar perairan dunia meningkat frekuensi, intensitas dan distribusi geografis selama beberapa dekade terakhir (Blondeau-Patissier, et al., 2014) termasuk di perairan Indonesia. Pada beberapa perairan di Indonesia seperti Teluk Jakarta (Prayitno \& Afdal, 2019) dan pesisir Sulawesi Selatan (Lukman et al., 2014) konsentrasi klorofil-a menunjukkan peningkatan. Meningkatnya konsentrasi klorofil-a di perairan tersebut seiring dengan tingginya konsentrasi nutrien diantaranya amonia dan silikat.

Sama dengan beberapa perairan lainnya di Indonesia, konsentrasi klorofil-a di perairan Teluk Doreri diperkirakan mengalami fluktuasi dengan cenderung mengalami peningkatan khususnya di bagian dalam teluk. Berdasarkan hal ini, penelitian ini bertujuan untuk mengetahui status berdasarkan konsentrasi klorofil-a serta hubungannya dengan amonia dan silikat di perairan Teluk Doreri, Kabupaten Manokwari, Provinsi Papua Barat.

\section{MATERI DAN METODE}

Penelitian berlangsung di perairan Teluk Doreri, Kabupaten Manokwari, Provinsi Papua Barat (Gambar 1). Pengambilan contoh air laut dilakukan pada kedalaman sekitar $50 \mathrm{~cm}$ dari permukaan laut. Contoh air laut diambil sebanyak tiga kali dengan interval satu kali setiap bulan secara berturut-turut pada 10 stasiun penelitian. Stasiun 1, 2 dan 3 berlokasi di pantai, tengah dan luar sebuah teluk kecil yang oleh masyarakat setempat disebut dengan Teluk Wosi dan stasiun 4 berada di perairan pantai tanjung BLK (Balai Latihan Kerja) Kabupaten Manokwari. Stasiun 5, 6 dan 7 berlokasi di bagian dalam Teluk Doreri berupa teluk kecil yang oleh masyarakat setempat disebut dengan Teluk Sawaibu. Stasiun 8 berlokasi di perairan antara dermaga PELNI (Pelabuhan Nasional Indonesia) dan RSUD (Rumah Sakit Umum Daerah Kabupaten Manokwari). Stasiun 9 
berlokasi di dermaga penyebrangan rakyat ke Pulau Mansinam dan Lemon serta stasiun 10 di perairan depan restoran Hotel Mansinam Beach Manokwari di Pantai Arowi.

Pengukuran konsentrasi klorofil-a, amonia dan silikat dilakukan dengan metode standar (APHA, 2005). Contoh air diambil pada setiap stasiun penelitian secara berturut-turut sebanyak $1000 \mathrm{ml}$. Contoh air dimasukkan ke dalam botol polietilen kapasitas $1000 \mathrm{ml}$ yang ditutup rapat dengan plastik polibek hitam. Selanjutnya contoh air disimpan dalam collbox bersuhu dingin untuk dianalisis secara eks situ di laboratorium. Pada laboratorium, contoh air laut disaring dengan milipore filter aparatus (Whatman GF/C, diameter $47 \mathrm{~mm}$ porositas $0,45 \mu \mathrm{m}$ ) dengan bantuan pompa vakum tekanan 200 $\mathrm{mm} \mathrm{Hg}$. Selanjutnya diekstraksi dengan aseton $90 \%$ sebanyak $10 \mathrm{ml}$ dan digerus sampai halus selama 10 sampai 15 menit. Setelah itu dimasukkan dalam tabung lalu ditutup dengan aluminium foil dan didinginkan dalam frizer pada suhu $0-4{ }^{\circ} \mathrm{C}$ selama 24-36 jam sebelum dianalisis. Setelah itu ditimbang lalu disentrifus pada putaran 3600 rpm selama 5 menit. Selanjutnya diukur dengan spektrofotometer (SHIMAZU UV-1601) pada panjang gelombang $750 \mathrm{~nm}$, dan 665 $\mathrm{nm}$. Selanjutnya ditambahkan asam dengan $1 \mathrm{~N} \mathrm{HCL}$ dan diukur pula pada panjang gelombang yang sama. Konsentrasi klorofil-a dihitung dengan menggunakan metode Lorenzen (1967) sebagai berikut :

$$
\text { Klorofil }-a(\mu g / L)=\frac{A^{*} K\left(665_{0}-665_{a}\right) * v}{V^{*} I}
$$

Keterangan : $\mathrm{A}=$ Koefisien absorpsi klorofil- $\mathrm{a}=$ 11,$0 ; \mathrm{K}=$ Faktor konversi absorbansi $=2,43$; $665 \circ=$ Absorbansi pada panjang gelombang $665 \mathrm{~nm}$ dikurangi absorbansi pada panjang gelombang $750 \mathrm{~nm}$ sebelum pengasaman; $665 a=$ Absorbansi pada panjang gelombang $665 \mathrm{~nm}$ dikurangi absorbansi pada panjang gelombang $750 \mathrm{~nm}$ setelah pengasaman; $v=$ Volume aseton yang digunakan untuk ekstraksi (ml); $\vee=$ Volume air yang disaring $(\mathrm{L}) ; \mathrm{I}=$ Panjang kuvet $(\mathrm{cm})$

Pengukuran konsentrasi amonia menggunakan metode Phenate dengan mengukur $25 \mathrm{ml}$ air laut tersaring lalu ditambahkan secara berturut-turut $1 \mathrm{ml}$ larutan fenol, $1 \mathrm{ml}$ larutan hipoklorit dan 2,5 ml larutan alkalin. Selanjutnya ukur absorbansinya dengan spektrofotometer pada panjang gelombang $640 \mathrm{~nm}$. Pengukuran konsentrasi silikat menggunakan metode Molibdosilikat dengan mengukur 10 $\mathrm{ml}$ air laut tersaring lalu ditambahkan $0,3 \mathrm{ml}$ larutan asam oksalat dan secara berturutturut $0,2 \mathrm{ml}$ asam askorbat dan oksalat. Ukur absorbansinya dengan spektrofotometer pada panjang gelombang $810 \mathrm{~nm}$.

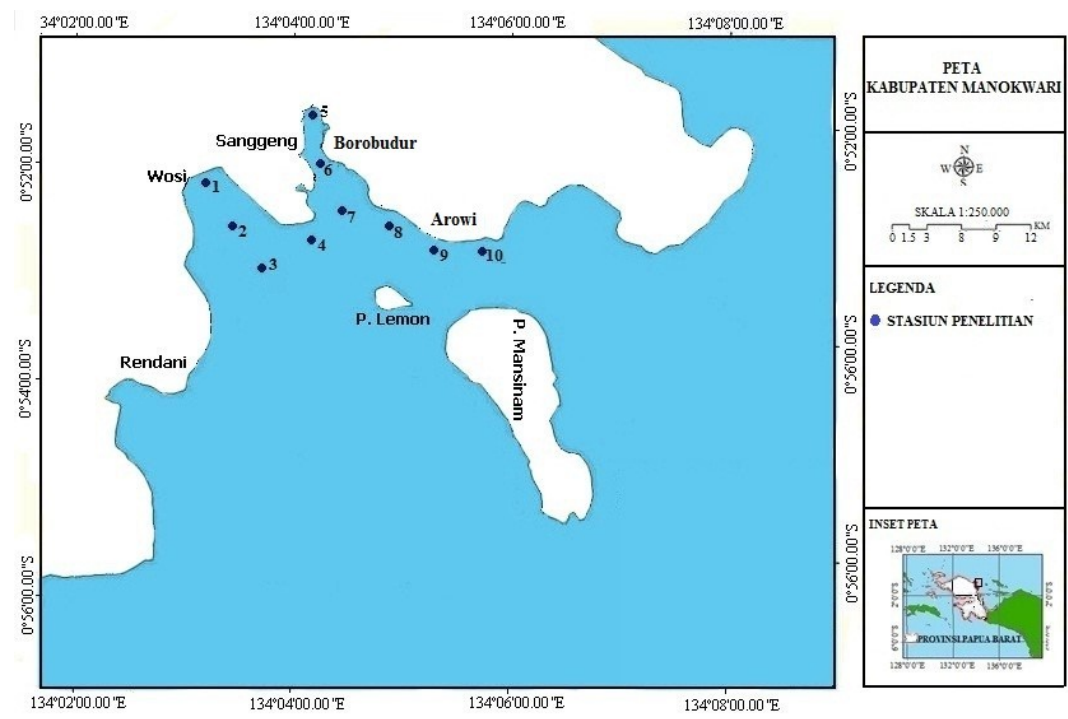

Gambar 1. Peta lokasi penelitian 
Distribusi konsentrasi klorofil-a, amonia dan silikat diuji dengan uji anova satu arah dan uji Post-HocDuncan. Hubungan klorofil-a dengan amonia dan silikat diuji dengan regresi linear. Kedua uji tersebut dilakukan dengan software IBM SPSS Statistics 23.

\section{HASIL DAN PEMBAHASAN}

Hasil pengukuran konsentrasi klorofil-a dari stasiun 1 sampai 10 dari $0,23-3,77 \mu \mathrm{g} / \mathrm{L}$ dengan rata-rata sebesar 0,82 $\mu \mathrm{g} / \mathrm{L}$ (Tabel 1). Tabel 1 menunjukkan konsentrasi klorofil-a relatif berbeda antara stasiun 1,5 dan 6 dengan Stasiun 2, 3, 4, 7, 8, 9, dan 10. Perbedaan tersebut ditunjukkan oleh nilai konsentrasi klorofil-a yang bervariasi antara stasiun tersebut. Walaupun demikian, konsentrasi klorofil-a cenderung lebih tinggi pada Stasiun 1 yang berkisar dari 1,02-3,77 $\mu \mathrm{g} / \mathrm{L}$ dengan rata-rata sebesar $1,57 \mu \mathrm{g} / \mathrm{L}$. Hal yang sama dengan konsentrasi klorofil-a di stasiun 5 berkisar dari 0,58 - 1,39 $\mathrm{\mu g} / \mathrm{L}$ dengan rata-rata sebesar 1,11 $\mathrm{gg} / \mathrm{L}$. Kondisi ini sampai Stasiun 6 dengan konsentrasi klorofil-a berkisar 0,46-1,26 $\mu \mathrm{g} / \mathrm{L}$ dengan rata-rata sebesar 1,08 $\mathrm{\mu g} / \mathrm{L}$. Sebaliknya, konsentrasi klorofil-a pada tujuh stasiun lainnya relatif homogen secara berturut-turut di stasiun 2, 3, 4, 7, 8, 9 dan 10 dengan nilai berada di bawah stasiun 1, 5 dan 6.

Perbedaan konsentrasi klorofil-a disebabkan posisi stasiun 1, 5 dan 6 berada di pantai yang bermuara 3 sungai yang membawa air tawar yang berasal dari pemukiman penduduk di Kelurahan Wosi, Sanggeng dan Padarni. Hal ini menyebabkan stasiun 1, 5 dan 6 secara langsung menerima bahan organik melalui buangan masa air tawar dari pemukiman di sekitarnya. Selain itu, secara tidak langsung stasiun 1, 5 dan 6 menerima bahan organik melalui aliran permukaan air tawar dari pemukiman sekitarnya. Bahan organik tersebut salah satunya terdapat dalam bentuk nutrien anorganik terlarut (Woodland et al., 2015). Selain itu, nutrien anorganik terlarut bersumber pula dari dalam perairan itu sendiri (Buzancic et al., 2016). Beberapa unsur nutrien anorganik terlarut yang dominan di perairan pantai di antaranya amonia (Glibert et al., 2016) dan silikat (Nincevic et al., 2015).
Keberadaan amonia dan silikat ini dapat meningkatkan konsentrasi klorofil-a khususnya di perairan pantai dan teluk yang dangkal. Hal ini ditunjukkan oleh konsentrasi klorofil-a di stasiun 1, 5 dan 6 berada di atas 1 $\mu \mathrm{g} / \mathrm{L}$ (Tabel 1 dan Gambar 2). Perairan dengan konsentrasi klorofil-a tinggi bila konsentrasinya berada di atas $1 \mu \mathrm{g} / \mathrm{L}$ (Chai et al., 2016). Perairan dengan konsentrasi klorofila sebesar ini menunjukkan pada perairan tersebut terjadi fenomena blooming fitoplankton (Guinder et al., 2015). Blooming fitoplankton dengan konsentrasi klorofil-a di atas $1 \mu \mathrm{g} / \mathrm{L}$ terjadi pula di perairan Pantai Maroon, muara Sungai Serang, muara sungai Leirisakaili, muara Sungai Angke, muara sungai Tallo, muara sungai Maros, muara sungai Pangkep dan muara sungai Silugonggo.

Konsentrasi klorofil-a di perairan pantai Maroon sebesar $1,09 \mathrm{mg} / \mathrm{m}^{3}$ (Prihatin et al., 2018) dan muara Sungai Serang dengan rata-rata sebesar $1,76 \mathrm{mg} / \mathrm{m}^{3}$ (Maslukah et al., 2017) setara dengan $1,09 \mu \mathrm{g} / \mathrm{L}$ dan 1,76 $\mu \mathrm{g} / \mathrm{L}$. Pada perairan muara Sungai Angke diperoleh konsentrasi klorofil-a dengan ratarata sebesar 3,19 $\mathrm{\mu g} / \mathrm{L}$ (Prayitno \& Afdal, 2019). Pada perairan muara sungai Tallo, Maros, dan Pangkep konsentrasi Klorofil-a secara berturut-turut dengan rata-rata sebesar 4,52 $\mathrm{\mu g} / \mathrm{L}, \quad 1,40 \mu \mathrm{g} / \mathrm{L}, \quad 2,72 \mu \mathrm{g} / \mathrm{L}$ (Lukman et al., 2014). Pada muara Sungai Silugonggo konsentrasi klorofil-a terendah dengan rata-rata sebesarl,4 $\mathrm{\mu g} / \mathrm{L}$ dan tertinggi 10,56 $\mathrm{mg} / \mathrm{L}$ (Hidayah et al., 2016). Sama halnya dengan Teluk Doreri, konsentrasi klorofil-a di perairan muara Sungai Serang, Muaraleisakaili, Angke, Tallo, Maros dan Pangkep semakin berkurang ke arah laut.

Konsentrasi klorofil-a pada 7 Stasiun (2, $3,4,7,8,9$, dan 10) yang mengarah ke luar teluk atau pantai yang berhadapan dengan laut lepas berada di bawah $1 \mathrm{\mu g} / \mathrm{L}$ (Gambar 2). Hal ini menunjukkan semakin ke luar teluk atau pantai yang berhadapan dengan laut lepas potensi terjadinya blooming fitoplankton semakin berkurang. Konsentrasi klorofil-a pada stasiun 2, 3, 4, 7, 8, 9, dan 10 tersebut secara berturut-turut dengan ratarata sebesar $0,96 \mu \mathrm{g} / \mathrm{L}, 0,80 \mu \mathrm{g} / \mathrm{L}, 0,52 \mu \mathrm{g} / \mathrm{L}$, $0,70 \mu \mathrm{g} / \mathrm{L}, \quad 0,58 \mu \mathrm{g} / \mathrm{L}, \quad 0,44 \mu \mathrm{g} / \mathrm{L}, \quad 0,37 \mu \mathrm{g} / \mathrm{L}$ (Tabel 1 dan Gambar 2). Konsentrasi klorofil-a pada stasiun $2,3,4,7$, dan 8 tergolong dalam 
Tabel 1. Konsentrasi klorofil-a di perairan Teluk Doreri

\begin{tabular}{|c|c|c|c|c|}
\hline \multirow[t]{2}{*}{ Stasiun } & \multicolumn{2}{|c|}{ Konsentrasi $(\mu \mathrm{g} / \mathrm{L})$} & & \\
\hline & Rata-rata & Standar Deviasi & Minimum & Maksimum \\
\hline 1 & $1.57^{*}$ & 0.90 & 1.02 & 3.77 \\
\hline 2 & 0.96 & 0.68 & 0.56 & 1.88 \\
\hline 3 & 0.80 & 0.32 & 0.46 & 1.10 \\
\hline 4 & 0.52 & 0.15 & 0.42 & 0.70 \\
\hline 5 & $1.21^{*}$ & 0.47 & 0.58 & 1.39 \\
\hline 6 & $1.08^{*}$ & 0.17 & 0.46 & 1.24 \\
\hline 7 & 0.70 & 0.23 & 0.24 & 0.66 \\
\hline 8 & 0.58 & 0.17 & 0.39 & 0.68 \\
\hline 9 & 0.44 & 0.11 & 0.34 & 0.56 \\
\hline 10 & 0.37 & 0.14 & 0.23 & 0.53 \\
\hline
\end{tabular}

Keterangan: *Berbeda nyata pada taraf $0.05 \%$

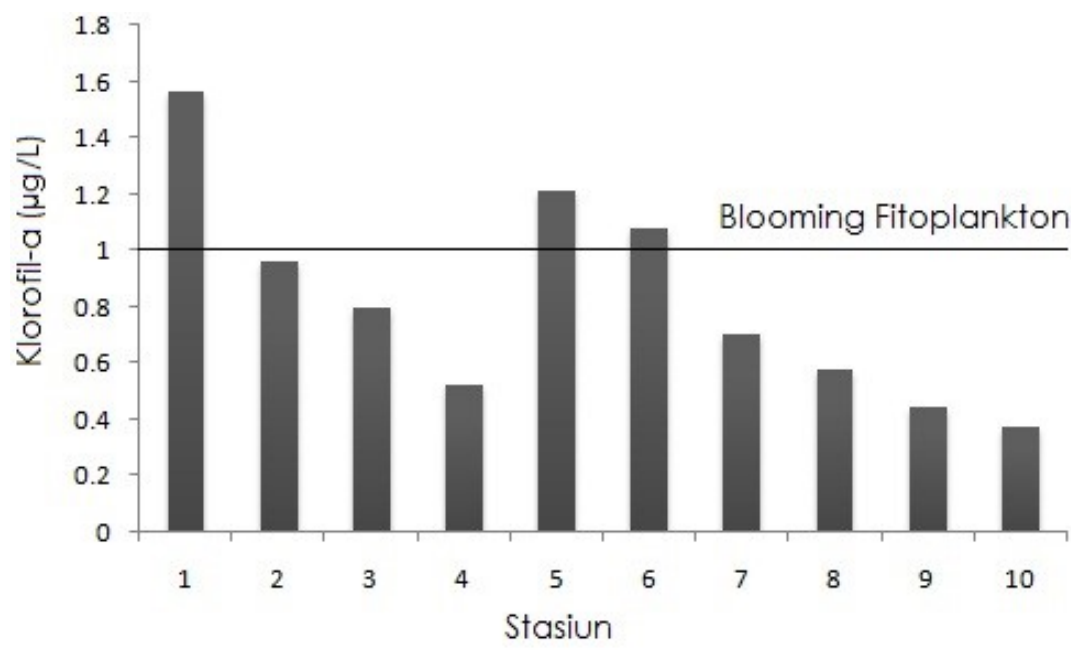

Gambar 2. Stasiun terjadinya blooming fitoplankton di perairan Teluk Doreri

kategori tinggi. Berbeda dengan konsentrasi klorofil-a pada stasiun 9 dan 10 tergolong dalam kategori sedang. Konsentrasi klorofil-a rendah bila berada di bawah $0,2 \mu \mathrm{g} / \mathrm{L}$ dan tinggi bila berada di atas $0,5 \mu \mathrm{g} / \mathrm{L}$ (Han \& Takahashi, 2000).

Konsentrasi klorofil-a di bagian luar Teluk Doreri termasuk stasiun 9 dan 10 berada di atas dari beberapa lokasi perairan laut lepas seperti perairan kepala burung Pulau Papua dan Pasifik Utara. Konsentrasi klorofil-a di perairan laut lepas kepala burung Pulau Papua seperti perairan luar Kabupaten Teluk Wondama, Manokwari, dan Biak serta Tambrauw secara berturut-turut dengan ratarata berkisar dari 0,24-0,36 $\mathrm{\mu g} / \mathrm{L}$ (Alianto et al., 2016). Hal yang sama dengan konsentrasi klorofil-a di perairan Pasifik Utara (arah utara timur Pasifik Utara) dengan rata-rata berkisar dari $0,17-0,33 \mu \mathrm{g} / \mathrm{L}$ (Han \& Takahashi, 2000).

Berkurangnya konsentrasi klorofil-a pada stasiun-stasiun yang mengarah ke bagian luar teluk atau pantai yang berhadapan dengan laut lepas disebabkan oleh semakin berkurangnya konsentrasi amonia dan silikat (Tabel 2). Hal ini disebabkan stasiun tersebut berada jauh dari pengaruh daratan yang merupakan sumber utama amonia dan silikat. Hal ini terlihat dari konsentrasi amonia dan silikat pada stasiun 2 , $3,4,7,8,9$ dan 10 secara berturut-turut berkisar dari 2,35-4,11 $\mu \mathrm{M}$ dengan rata-rata sebesar 2,64 $\mu \mathrm{M}$ dan 2,00-7,50 $\mu \mathrm{M}$ dengan rata-rata sebesar 3,91 $\mu \mathrm{M}$ (Tabel 2). 
Konsentrasi amonia dan silikat pada stasiun 2, $3,4,7,8,9$ dan 10 jauh lebih rendah 2 sampai 4 kali dari stasiun 1, 5 dan 6 (Tabel 1 dan 2).

Konsentrasi yang sama dengan bagian luar Teluk Doreri dijumpai pula pada perairan lainnya di Indonesia seperti perairan luar Teluk Wondama dan perairan kepulauan Banggai. Konsentrasi amonia dan silikat di perairan luar Teluk Wondama secara berturut-turut dengan rata-rata sebesar 2,35 $\mu \mathrm{M}$ dan 5,16 MM (Alianto et al., 2016). Hal yang sama dengan konsentrasi silikat di perairan kepulauan Banggai dengan rata-rata sebesar 7,00 $\mu \mathrm{M}$ (Thoha dan Rachman, 2013).

Walaupun demikian, konsentrasi amonia yang mengarah ke luar teluk atau pantai yang berhadapan dengan laut lepas ini tetap menyokong ketersediaan klorofil-a. Hal ini ditunjukkan adanya hubungan positif dengan klorofil-a (Gambar 3). Hal yang sama terjadi pula di perairan lainnya di Indonesia seperti perairan luar Teluk Wondama (Alianto et al., 2018). Hal ini menunjukkan bahwa keberadaan klorofil-a di perairan terutama luar teluk sangat bergantung pada ketersediaan amonia. Selain itu, hubungan seperti ini menunjukkan pula bahwa sumber klorofil-a di perairan sebagian berasal dari kelompok fitoplankton yang jumlah jenisnya tidak terbanyak di perairan. Fenomena ini seperti terjadi di perairan luar Teluk Wondama yang menunjukkan hubungan positif antara amonia dengan fitoplankton dominan yang berasal dari kelompok fitoplankton yang jumlah jenisnya tidak terbanyak di perairan (Alianto et al., 2018).

Hal di atas sejalan dengan hasil penelitian lainnya yang menunjukkan kelimpahan fitoplankton tertinggi di perairan Teluk Doreri berasal dari kelompok fitoplankton yang jumlah jenisnya tidak terbanyak di perairan (Atururi, 2014). Hubungan seperti ini menunjukkan pula bahwa kelompok fitoplankton yang jumlah jenisnya tidak terbanyak di perairan sangat bergantung pada amonia. Hal ini diperjelas dengan adanya hubungan negatif antara

Tabel 2. Konsentrasi amonia dan silikat di perairan Teluk Doreri

\begin{tabular}{ccccccccc}
\hline & \multicolumn{9}{c}{ Konsentrasi $(\mu M)$} \\
\cline { 2 - 8 } Stasiun & \multicolumn{9}{c}{ Amonia } & \multicolumn{3}{c}{ Silika } \\
\cline { 2 - 9 } & $\begin{array}{c}\text { Rata } \\
\text {-rata }\end{array}$ & $\begin{array}{c}\text { Standar } \\
\text { Deviasi }\end{array}$ & Minimum & Maksimum & $\begin{array}{c}\text { Rata- } \\
\text { rata }\end{array}$ & $\begin{array}{c}\text { Standar } \\
\text { Deviasi }\end{array}$ & Minimum & Maksimum \\
\hline 4 & 2.35 & 0.00 & 2.35 & 2.94 & 5.66 & 1.83 & 3.66 & 7.50 \\
8 & 2.94 & 0.58 & 2.35 & 4.11 & 2.66 & 1.00 & 2.00 & 3.83 \\
9 & 2.94 & 0.00 & 2.94 & 3.52 & 3.00 & 0.83 & 2.50 & 4.16 \\
10 & 2.35 & 0.00 & 2.94 & 2.94 & 4.33 & 1.83 & 2.50 & 6.33 \\
\hline
\end{tabular}

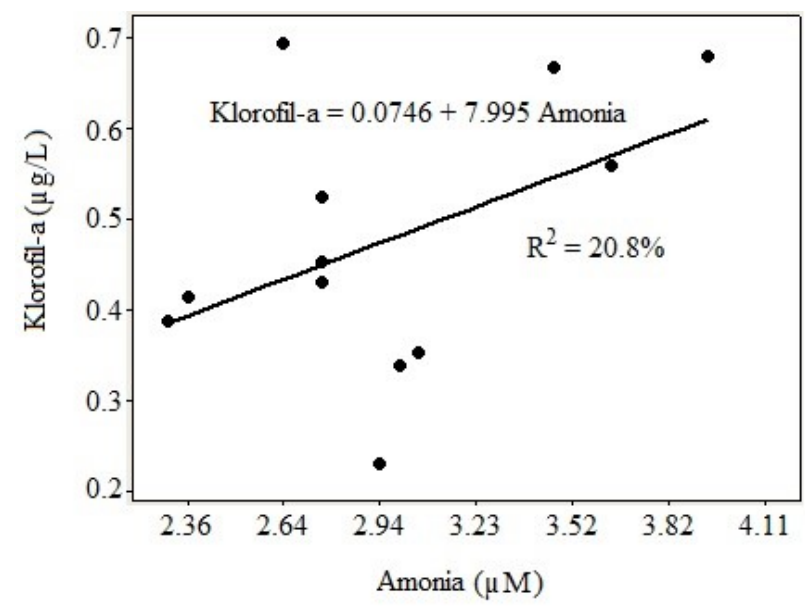

Gambar 3. Hubungan klorofil-a dengan amonia di perairan Teluk Doreri 


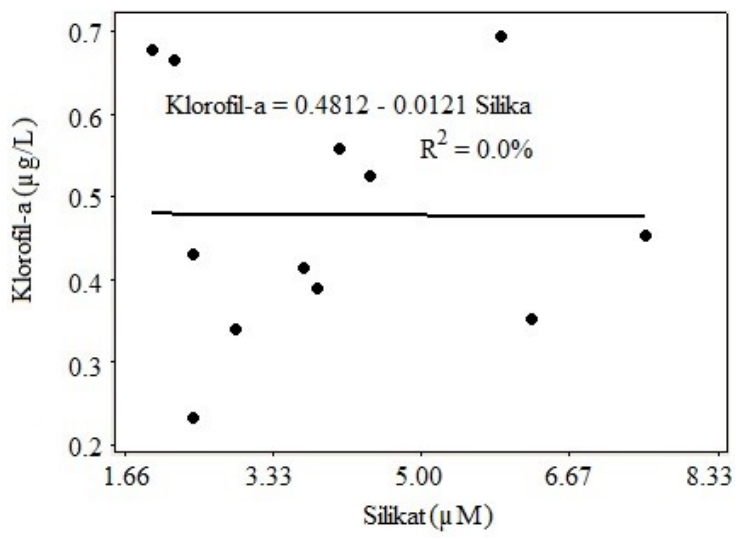

Gambar 4. Hubungan klorofil-a dengan silikat di perairan Teluk Doreri

klorofil-a dengan silikat di perairan Teluk Doreri (Gambar 4). Hubungan yang sama terjadi pula pada perairan lainnya diantaranya luar Teluk Wondama (Alianto et al., 2018) dan pesisir Sulawesi Selatan seperti muara Sungai Tallo, Maros dan Pangkep (Lukman et al., 2014).

\section{KESIMPULAN}

Status blooming fitoplankton ditunjukkan konsentrasi klorofil-a pada stasiunstasiun di pantai sekitar muara sungai yang alirannya melewati pemukiman padat penduduk dan tengah yang tidak berhadapan dengan laut lepas di bagian dalam Teluk Doreri dengan kategori tergolong tinggi. Konsentrasi klorofil-a pada stasiun-stasiun di perairan pantai yang mengarah ke luar teluk atau sebagian besar mendapat pengaruh laut atau berhadapan dengan laut lepas dengan kategori tergolong sedang. Hubungan konsentrasi klorofil-a dengan amonia dan silikat secara berturut-turut menunjukkan hubungan positif dan negatif.

\section{DAFTAR PUSTAKA}

Alianto, Hendri, \& Suhaemi. 2018. Kelimpahan dan kelompok fitoplankton di perairan luar Teluk Wondama, Provinsi Papua Barat. J. Ilmu dan Teknologi Kelautan Tropis. 10(3):683-697. doi: 10.29244/jitkt .v10i3.19561

Alianto, Saleh, F.I.E., Hendri, Suhaemi, Gaite, T., Awak, N.V. \& Rumbewas, H.S.R. 2016. Sebaran klorofil-a di daerah fishing ground ikan pelagis besar perairan kepala burung Pulau Papua. Prosiding seminar nasional tahunan XIII hasil penelitian perikanan dan kelautan. Jilid II Manajemen Sumberdaya Perikanan, Universitas Gadjah Mada. pp: PI-1 1

APHA (American Public Health Association). 2005. Standard Methods for the Examination of Water and Wastewater. $21^{\text {th }}$ Edition. APHA, AWWA (American Water Works Association), and WPCF (Water Pollution Control Federation), Washington.

Blondeau-Patissier, D., Gower, J.F.R., Dekker, A.G., Phinn, S.R. \& Brando, V.E., 2014. A review of ocean color remote sensing methods and statistical techniques for the detection, mapping and analysis of phytoplankton blooms in coastal and open oceans. Prog. Oceanogr. 123(4): 123-144. doi:10.1016/j.pocean.2013.12.0 08

Buzancic, M., Gladan, Z.N., Marasovic, I., Kuspilic, G. \& Grbec, B. 2016. Eutrophication influence on phytoplankton community composition in three bays on the eastern Adriatic coast. Oceanologia. 58(4): 302-316. doi: 10.1016/j.oceano. 2016.05 .003

Chai, C., Jiang, T., Cen, J., Ge, W. \& Lu, S. 2016. Phytoplankton pigments and functional community structure in relation to environmental factors in the Pearl River Estuary. Oceanologia. 58(3): 201-211. doi: 10.1016/j.oceano.2016.03.001

Chakraborty, S. \& Feudel, U. 2014. Harmful algal blooms: combining excitability and competition. Theo. Ecol. 7(1): 221-237 
Glibert, P.M., Wilkerson, F.P., Dugdale, R.C., Raven, J.A., Dupont, C.L., Leavitt, P.R., Parker, A.E., Burkholder, J.M. \& Kana, T.M. 2016. Pluses and minuses of ammonium and nitrate uptake and assimilation by phytoplankton and implications for productivity and community composition, with emphasis on nitrogenenriched conditions. Limnol. Oceanogr. 61 (1): 165-197. doi: /10.1002/Ino.10203

Guinder, V.A., López-Abbate, M.C., Berasategui, A.A., Negrin, V.L., Zapperi, G., Pratolongo, P. D., Fernández S.M.D. \& Popovich, C.A. 2015. Influence of the winter phytoplankton bloom on the settled material in a temperate shallow estuary. Oceanologia. 57(1):50-60. doi: 10.1016/j.oceano.2014.10.002

Han, D.O. \& Takahashi, M.M. 2000. Chlorophyll-a biomass of netplankton in surface waters of the Northern North Pacific Ocean and the adjacent seas from summer to autumn. J. Oceanogr. 56(2):213-222

Hidayah, G., Wulandari, S.Y. \& Zainuri, M. 2016. Studi sebaran klorofil-a secara horisontal di perairan Sungai Silugonggo Kecamatan Batangan, Pati. Buletin Oseanografi Marina. 5(1):52-59. doi: 10.14 710/buloma.v5i1.11296

Hourany, R.L., Fadela, A., Gemayelb, E., Saabb, E.A. \& Faour, G. 2017. Spatiotemporal variability of the phytoplankton biomass in the Levantine basin between 2002 and 2015 using MODIS products. Oceanologia. 59(2): 153-165. doi: 10.1016 /j.oceano.2016.12.002

Lukman, M., Nasir, A., Amri, K., Tambaru, R., Hatta, M., Nurfadilah, \& Rahmat, J.N. 2014. Silikat terlaut di perairan pesisir Sulawesi Selatan. J. Ilmu dan Teknologi Kelautan Tropis. 6(2): 461-478

Lorenzen, C.J. 1967. Determination of chlorophyll and phaepigments: spectrophotometric equations. Limnol. Oceanogr. 12(2): 343-346

Maslukah, L., Wulandari, S.L. \& Prasetyawan, I.B. 2017. Konsentrasi klorofil-a dan keterkaitannya dengan nutrient $\mathrm{N}, \mathrm{P}$ di perairan Jepara: studi perbandingan perairan muara Sungai Wiso dan Serang. J. Kel. Trop., 20(2):72-77. doi: 10.14710 /jkt.v20i2.1697
Nincevic G.Ž., Bužancic, M., Kušpilic, G., Grbec, B., Matijevic, S., Skejic, S., Marasovic, I. \& Morovic, M. 2015. The response of phytoplankton community to anthropogenic pressure gradient in the coastal waters of the eastern Adriatic Sea. Ecol. Indic. 56(10):106-115. doi: 10.1016/j.ecolind.2015.03.018

Prayitno, H.B. \& Afdal. 2019. Spatial distributions of nutrients and chlorophylla: a possible occurrence of phosphorus as a eutrophication determinant of the Jakarta Bay. J. Ilmu Teknolog. Kel. Trop., 11 (1):1-12. doi: 10.29244/jitkt.v1 1i1.21971

Prihatin, A., Setyono, P. \& Sunarto. 2018. Sebaran klorofil-a, nitrat, fosfat dan plankton sebagai indikator kesuburan ekosistem di mangrove Tapak Tugurejo Semarang. J. Ilmu Lingkungan., 16(1): 6877. doi: 10.14710/jil.16.1.68-77

Rimet, F. \& Bouchez, A. 2012. Biomonitoring river diatoms: implications of taxonomic resolution. Ecol. Indic., 15(1): 92-99

Rozema, P.D., Venables, H. J., Van de Poll, W. H., Clarke, A., Meredith, M. P. \& Buma, A. G. J. 2017. Interannual variability in phytoplankton biomass and species composition in northern Marguerite Bay (West Antarctic Peninsula) is governed by both winter sea ice cover and summer stratification. Limnol. Oceanogr., 62(1): 235-252. doi: 10.1002/Ino.10391

Szymczak-Zylaa, M., Magdalena K., Aleksandra W., Agata Z., Gijs D.B. \& Grazyna K. 2017. Tracking trends in eutrophication based on pigments in recent coastal sediments. Oceanologia, 59 (1):1-17 doi:10.1016/j.oceano.2016.08.0 03

Szymczak-Zylaa, M., Kowalewska, G. \& Louda, J.W., 2011. Chlorophyll-a and derivatives in recent sediments as indicators of productivity and depositional conditions. Mar. Chem., 125(1-4):39-48. doi: 10.1016 /j.marchem.2011.02.002

Thoha, H. \& Rachman, A. 2013. Kelimpahan dan distribusi spasial komunitas plankton di perairan Kepulauan Banggai. J. Ilmu Teknolog. Kel. Trop., 5(1):145-161

Woodland, R.J., Thomson, J.R., Nally, R.M., Evrard, V., Wary, F.Y., Walker, J.P. \& Cook, P.L.M. 2015. Nitrogen loads explain primary productivity in estuaries at the ecosystem scale. Limnol. Oceanogr., 60(5):1751-1762. doi: 10.1002/Ino.10136 